\title{
The Quintuple Helix innovation model: global warming as a challenge and driver for innovation
}

\author{
Elias G Carayannis ${ }^{1 *}$, Thorsten D Barth ${ }^{2}$ and David F J Campbell ${ }^{3,4}$
}

\begin{abstract}
The Triple Helix innovation model focuses on university-industry-government relations. The Quadruple Helix embeds the Triple Helix by adding as a fourth helix the 'media-based and culture-based public' and 'civil society'. The Quintuple Helix innovation model is even broader and more comprehensive by contextualizing the Quadruple Helix and by additionally adding the helix (and perspective) of the 'natural environments of society'. The Triple Helix acknowledges explicitly the importance of higher education for innovation. However, in one line of interpretation it could be argued that the Triple Helix places the emphasis on knowledge production and innovation in the economy so it is compatible with the knowledge economy. The Quadruple Helix already encourages the perspective of the knowledge society, and of knowledge democracy for knowledge production and innovation. In a Quadruple Helix understanding, the sustainable development of a knowledge economy requires a coevolution with the knowledge society. The Quintuple Helix stresses the necessary socioecological transition of society and economy in the twenty-first century; therefore, the Quintuple Helix is ecologically sensitive. Within the framework of the Quintuple Helix innovation model, the natural environments of society and the economy also should be seen as drivers for knowledge production and innovation, therefore defining opportunities for the knowledge economy. The European Commission in 2009 identified the socioecological transition as a major challenge for the future roadmap of development. The Quintuple Helix supports here the formation of a win-win situation between ecology, knowledge and innovation, creating synergies between economy, society, and democracy. Global warming represents an area of ecological concern, to which the Quintuple Helix innovation model can be applied with greater potential.
\end{abstract}

Keywords: Knowledge production, Innovation, Triple Helix, Quadruple Helix, Quintuple Helix, Social ecology, Global warming, Knowledge economy, Knowledge society, Knowledge democracy

\section{Background}

'Global warming' represents an ecological (also socioecological) issue of importance and concern. Due to the escalation of global warming, it is time for humanity to think and act responsibly and determine sustainable solutions. Global warming, in addition to climate change, has caused the world to undertake new responsibilities (see IPPC 2007a), which not only include further climate change, but in the long term, also hold humanity accountable in the prevention of new political and/or social conflicts, war on resources, new environmental catastrophes as well as serious crises in the

\footnotetext{
* Correspondence: caraye@gwu.edu

'Department of Information Systems and Technology Management, George Washington University, School of Business, Washington, DC 20052, USA Full list of author information is available at the end of the article
}

market economies (see UNDP 2007; UNEP 2008). The special challenge of global warming can be tackled by 'sustainable development'. Sustainable development concerns us all and takes place on the local as well as global level. Hence, sustainable development has to be understood in the context of 'gloCal knowledge economy and society' (see Carayannis and Campbell 2011; Carayannis and von Zedtwitz 2005; Carayannis and Alexander 2006). Therefore, we must perceive global warming not as a challenge but rather as an opportunity to live innovatively and effectively in union with nature for a better tomorrow.

To a large extent, humanity itself has caused the climate change; therefore, something must be done (see IPPC 2007b; Le Monde diplomatique 2009, pp. 72-73; Friedman 2008). However, there are hardly any comprehensive 
models or concepts to answer the 'Why' that truly shows 'How' we can act and learn accordingly or provide any demonstrative methods, suggestions, and examples how we can improve our actions in the present. Our analysis presented here suggests understanding the 'why' and consequently, offers a 'model of innovation' which demonstrates a feasible, step-by-step method to tackle the 'how'.

In the current academic debate, it is undisputed that a solution or a suitable answer regarding the challenge of global warming can only be found through utilizing the asset of human knowledge (see Carayannis and Campbell 2010, p. 42; Bhaskar 2010, p. 1). The key to success, as being determined by our propositions, lies in using the available and newly created 'knowledge' in correspondence with the Quintuple Helix Model (Carayannis and Campbell 2010, p. 62). The Quintuple Helix is a model of innovation that can tackle existing challenges of global warming through the application of knowledge and know-how as it focuses on the social (societal) exchange and transfer of knowledge inside the subsystems of a specific state or nation-state (see Barth 2011a, pp. 5-7). The 'nonlinear' innovation model of the Quintuple Helix, which combines knowledge, know-how, and the natural-environment-system together into one 'interdisciplinary' and 'transdisciplinary' framework, can provide a step-by-step model to comprehend the qualitybased management of effective development, recover a balance with nature, and allow future generations a life of plurality and diversity on earth (see Carayannis and Campbell 2010, p. 42; Barth 2011a, p. 2). To sum up, our thesis is as follows: the Quintuple Helix represents a suitable model in theory and practice offered to society to understand the link between knowledge and innovation, in order to promote a lasting development. This contribution, under the aspect of global warming, focuses on the potential of a nation-state in the twenty-first century and on the following pivotal question: How can sustainable development, with regard to global warming, be practiced step-by-step with and within a Quintuple Helix model?

The structure of our analysis is as follows. The Section 'The challenge of global warming and the resource of knowledge' is a short delineation about challenges of global warming and the organization of the resource of knowledge. In Section 'What is a Quintuple Helix model?', the Quintuple Helix model is defined. Next comes Section 'The challenge of global warming in a Quintuple Helix Model' that visualizes the Quintuple Helix model as a nonlinear model of innovation in correspondence with social (societal) subsystems and along with a descriptive step-by-step example of how the challenge of sustainable development (under the aspect of global warming) may be adopted. Section 'Conclusions' offers a conclusion in reference to the Quintuple Helix Model.

\section{Results and discussion}

\section{The challenge of global warming and the resource of knowledge}

The challenge of sustainable development (under the aspect of global warming) proves that there are currently several crucial questions that need to be answered (see Carayannis 2011); so new political goals must be formulated, in reference with $\mathrm{CO}_{2}$ emission limits, in the quest for a long-term sustainability. Furthermore, there is rising demand for 'new green' knowledge solutions and know-how in order to utilize resources innovatively for society and the economy in an environmentally conscious manner. Moreover, our present way of life and lifestyle must be scrutinized under a sustainable impact assessment. Apart from the environmental protection, it also demands the protection of biodiversity (see Barth 2011a; Bhaskar 2010; Le Monde diplomatique 2009, pp. 22-23, 72-73, 92-93; UNDP 2007). Global warming concerns us all as it takes place on a local as well as global level and implies ramifications for the gloCal knowledge economy and society (see Carayannis and Campbell 2011; Carayannis and von Zedtwitz 2005; Carayannis and Alexander 2006). It is clear that the challenge of global warming is accompanied with the challenge of sustainability (for the world) in the twentyfirst century (see Carayannis 2011). Therefore, there are nine areas, of which Carayannis and Kaloudis write about, that require 'sustained action', political and economical 'leadership' or 'empowerment', and 'intelligent use of technology' (Carayannis and Kaloudis 2010, p. 2):

1.) "Financial/economic system" ;

2.) "Environmental challenges"c;

3.) "Feed and heal the world challenges",

4.) "Energy challenges",

5.) "Educational challenges",

6.) "Political democratic reform across the world",

7.) "Transformative government across the world",

8.) "Equity and Security across the world",

9.) "Technology, innovation and entrepreneurship as drivers of knowledge societies".

Let us consider now in greater detail the production of the resource of knowledge. Knowledge (for example, the advancement of green technology) can act as key to success for sustainable development. Essentially, it should be understood today that nation-states that concentrate on the progress of society, higher competitiveness of their economies, or better and sustainable quality of life have to apply the resource of knowledge. In the transformation to a knowledge-based society, knowledge-based economy, or knowledge-based democracy (see Carayannis and Campbell 2009, p. 224), also under the aspect of climate change, it is possible to generate new and 
usable knowledge in conjunction with sustainable development. The resource of knowledge, therefore, turns into the 'most fundamental resource' (Lundvall 1992, p. 1), with qualities of a 'knowledge nugget' (Carayannis and Formica 2006, p. 152). Knowledge, as a resource, is created through creative processes, combinations, and productions in socalled 'Knowledge models' or 'Innovation models' and thus becomes available for society: 'We can also call this the creativity of knowledge creation' (Carayannis and Campbell 2010, p. 48). We want to refer here specifically the six currently existing models of knowledge creation and innovation creativity (see also Figure 1 and Carayannis and Campbell 2012, pp. 13-28) as follows:

Mode 1 (Gibbons et al. 1994). Mode 1 'focuses on the traditional role of university research in an elderly "linear model of innovation" understanding, and success in mode 1 'is defined as a quality or excellence that is approved by hierarchically established peers' (Carayannis and Campbell 2010, p. 48).

Mode 2 (see Gibbons et al. 1994). Mode 2 can be characterized by the following five principles: (1) 'knowledge produced in the context of application'; (2) 'transdisciplinarity'; (3) 'heterogeneity and organizational diversity'; (4) 'social accountability and reflexivity'; (5) and 'quality control' (Gibbons et al. 1994, pp. 3-4).

Triple Helix (see Etzkowitz and Leydesdorff 2000). The 'Triple Helix overlay provides a model at the level of social structure for the explanation of mode 2 as an historically emerging structure for the production of scientific knowledge, and its relation to Mode 1, and it is a "model of "trilateral networks and hybrid organizations" of "university-industry-government relations"' (Etzkowitz and Leydesdorff 2000, pp. 118, 111-112).
Mode 3 (see Carayannis and Campbell 2006). 'The concept of mode 3 is more inclined to emphasize the coexistence and coevolution of different knowledge and innovation modes. Mode 3 even accentuates such pluralism and diversity of knowledge and innovation modes as being necessary for advancing societies and economies. This pluralism supports the processes of a mutual cross-learning from the different knowledge modes. Between mode 1 and mode 2 manifold creative arrangements and configurations are possible, linking together basic research and problem-solving' (Carayannis and Campbell 2010, p. 57). Mode 3 'encourages interdisciplinary thinking and transdisciplinary application of interdisciplinary knowledge' as well as 'allows and emphasizes the coexistence and coevolution of different knowledge and innovation paradigms' (see Carayannis and Campbell 2010, pp. 51-52).

Quadruple Helix (see Carayannis and Campbell 2009). The Quadruple Helix model is based on the Triple Helix model and adds as fourth helix the 'public', more specifically being defined as the 'media-based and culture-based public' and civil society. This 'fourth helix associates with "media", "creative industries", "culture", "values", "lifestyles", "art", and perhaps also the notion of the "creative class"' (Carayannis and Campbell 2009, pp. 218, 206)

Quintuple Helix (see Carayannis and Campbell 2010). The Quintuple Helix model is based on the Triple Helix model and Quadruple Helix model and adds as fifth helix the 'natural environment'. The Quintuple Helix is a 'five-helix model,' 'where the environment or the natural environments represent the fifth helix' (Carayannis and Campbell 2010, p. 61): 'The Quintuple Helix can be proposed as a framework for transdisciplinary (and interdisciplinary) analysis of

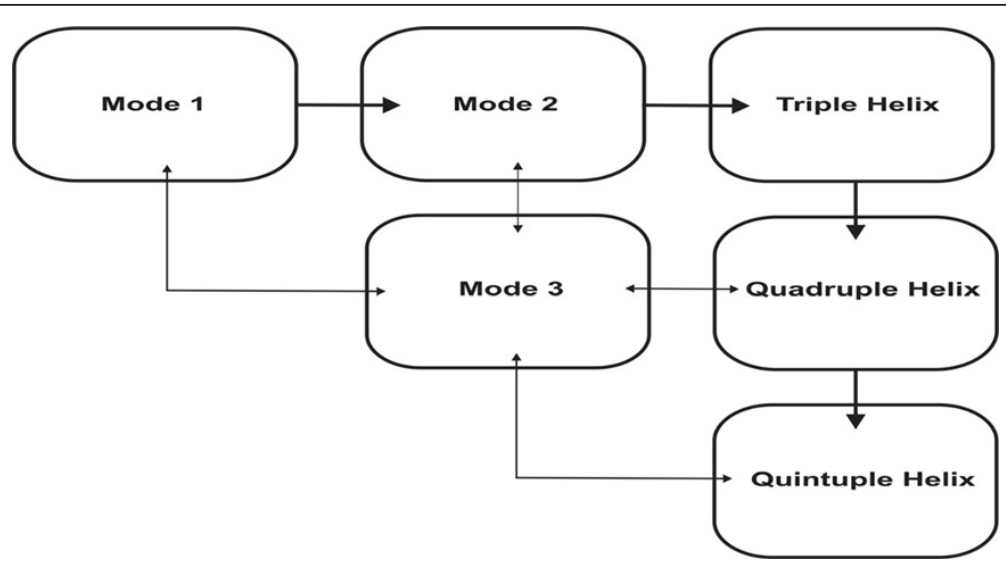

Figure 1 The evolution of the models of knowledge creation. 
sustainable development and social ecology'

(Carayannis and Campbell 2010, p. 62) (see also later our analysis in Section 'What is a Quintuple Helix

Model?').

About these six briefly described models, it can be concluded that in a knowledge society (and knowledge democracy), at the national level, a network-style linkage of knowledge is being processed; each model fulfills a specific contribution for the 'creation, diffusion, and use of knowledge' (see Carayannis and Campbell 2006, 2010). In reference to sustainable development, under the aspect of global warming, we should add whether in the future a state (nationstate) that is leading in world politics as well as in the world economy is also being determined by the social (societal) potential to balance new knowledge, know-how, and innovation with nature. The basic innovation 'core model' of the Triple Helix focuses on the knowledge economy. Quadruple Helix already brings in the perspective of the knowledge society (and of knowledge democracy). From the point-ofview of the Quadruple Helix innovation model, it is evident that there should be a coevolution of the knowledge economy and of knowledge society (see also Dubina et al. 2012). The Quintuple Helix finally stresses the socioecological perspective of the natural environments of society. Social ecology focuses on the interaction, codevelopment and coevolution of society, and nature (Carayannis and Campbell 2010, p. 59). The 'biophysical structures' or 'biophysical structures of society' mark areas of an overlap between culture (the cultural) and nature (the natural). Furthermore, between these biophysical structures and nature, there operates a metabolism (a 'social metabolism', with the potential of a 'sociometabolic transition'). Here, also specific 'metabolic profiles' apply (see Fischer-Kowalski 1998; Fischer-Kowalski and Hüttler 1999; Fischer-Kowalski and Haberl 2007; Haberl et al. 2004, pp. 201-202, 204; see also Hopwood et al. 2005; Kates et al. 2001). 'Sociometabolic regimes represent dynamic equilibria of society-nature interactions and are characterized by typical patterns of material and energy flows (metabolic profiles)' (Krausmann et al. 2008, p. 1). The European Commission (2009) identified the 'socioecological transition' as one of the major challenges for current and future societies and economies. The Quintuple Helix innovation model offers here an answer that is oriented toward problem-solving and sustainable development, furthermore, indicating how this socioecological transition may be mastered in combination with knowledge production and innovation (see Figure 2). In fact, this socioecological transition behaves also as a (social) driver for innovation, creating incentives for more knowledge and better innovation.

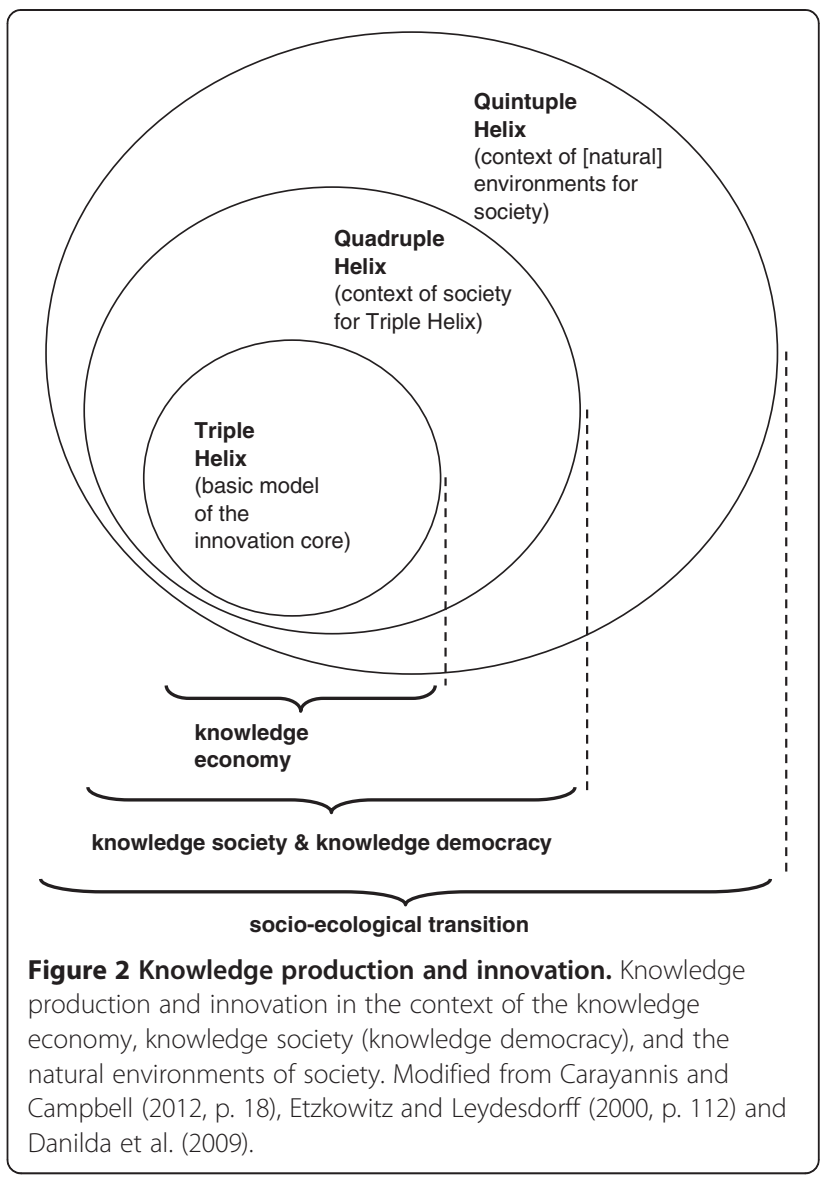

Hence, for more details, we look closer at the Quintuple Helix model in the following Section, 'What is a Quintuple Helix Model?'.

\section{What is a Quintuple Helix Model?}

Knowledge in a Quintuple Helix Model is the pivotal force and driver for progress. The Quintuple Helix is a model which grasps and specializes on the sum of the social (societal) interactions and the academic exchanges in a state (nation-state) in order to promote and visualize a cooperation system of knowledge, know-how, and innovation for more sustainable development (see Carayannis and Campbell 2010, p. 62). The specialty of the Quintuple Helix Model can thus be described in the following way:

'The Quintuple Helix Model is interdisciplinary and transdisciplinary at the same time: the complexity of the five-helix structure implies that a full analytical understanding of all helices requires the continuous involvement of the whole disciplinary spectrum, ranging from the natural sciences (because of the natural environment) to the social sciences and 
humanities (because of society, democracy and the economy)' (Carayannis and Campbell 2010, p. 62)

Thus, the goal of the Helix-Conception is accomplished through the resource of knowledge which produces additional value for society in order to lead in the field of sustainable development. The pivotal question of the Quintuple Helix defines itself in the following way:

'How do knowledge, innovation and the environment (natural environment) relate to each other?'

(Carayannis and Campbell 2010, p. 42)

The analytical point of origin of the Quintuple Helix, as described in the Section 'The challenge of global warming and the resource of knowledge', is the Triple Helix Model of Etzkowitz and Leydesdorff (2000) and is the Quadruple Helix Model of Carayannis and Campbell (2010). The social (societal) cooperation system defines itself based on the model of a Triple Helix, which consists of a combination of university (i.e., education system), industry (i.e., economic system), and government (i.e., political system) (see Etzkowitz and Leydesdorff 2000, pp. 111-112). To this combination the authors (Etzkowitz and Leydesdorff) refer to it as 'university-industry-government relations', linking together the creation and exchange of knowledge between these three subsystems. Carayannis and Campbell acknowledged the nonlinear dynamics within the Triple Helix and extended this to the Quadruple Helix (see Carayannis and Campbell 2009, p. 218): The Triple Helix is broadened within the Quadruple Helix through a media-based and culture-based public subsystem. The purpose of this extension is to include the public as well as the civil society as a fourth subsystem. The media-based public not only supports the diffusion of knowledge in a state (nation-state), but also the culture-based public with its values, experience, traditions, and visions, which promotes knowledge for the knowledge society (Carayannis and Campbell 2009, pp. 217-227). Let us now have a closer look at the Quintuple Helix Model. In the year 2010, authors Carayannis and Campbell developed the Quadruple Helix further by adding a fifth helix to the modeling of knowledge and innovation, being the natural environment. The Quadruple Helix developed into the Quintuple Helix (see Figure 3) (Carayannis and Campbell 2010, p. 62).

The goal and interest of the Quintuple Helix are to include natural environment as a new subsystem for knowledge and innovation models, so that 'nature' becomes established as a central and equivalent component of and for knowledge production and innovation. The natural environment is for the process of knowledge production, and the creation of a new innovation is particularly important because it serves for the preservation, survival, and vitalization of humanity, and the possible making of new green technologies; and humankind, after all, should learn more from nature (especially in times of climate change). With the Helix of Natural Environment, 'sustainable development' and 'social ecology' become constituents for social (societal) innovation and knowledge production (Carayannis and Campbell 2010, pp. 58-62):

"The Quintuple Helix furthermore outlines what sustainable development might mean and imply for 'eco-innovation' and 'eco-entrepreneurship' in the current situation and for our future" (Carayannis and Campbell 2010, pp. 62-63).

The most important constituent element of the Quintuple Helix - apart from the active 'human agents' - is the resource of 'knowledge', which, through a circulation (i.e., circulation of knowledge) between social (societal) subsystems, changes to innovation and knowhow in a society and for the economy (see Barth 2011a, p. 6). The Quintuple Helix, thereby, visualizes the collective interaction and exchange of knowledge in a state (nation-state) by means of the following five subsystems (i.e., helices): (1) education system, (2) economic system, (3) natural environment, (4) mediabased and culture-based public (also civil society), (5) and the political system (see Carayannis and Campbell 2010, pp. 46-48, 62). To analyze sustainability in a Quintuple Helix and to make sustainable development determination for progress therefore means that each of the five described subsystems (helices) has a special and necessary asset at its disposal, with a social (societal) and academic (scientific) relevance for use (see Figure 3; see also Barth 2011a, p. 6 and 2011b, pp. 30-31; Meyer 2008, pp. 89-95; Carayannis 2004, pp. 49-50), as follows:

(1) The education system: The education system, as the first subsystem, defines itself in reference to 'academia,' 'universities,' 'higher education systems', and schools. In this helix, the necessary 'human capital' (for example: students, teachers, scientists/ researchers, academic entrepreneurs, etc.) of a state (nation-state) is being formed by diffusion and research of knowledge.

(2) The economic system: The economic system, as the second subsystem, consists of 'industry/industries', 'firms', services and banks. This helix concentrates and focuses the 'economic capital' (for example: entrepreneurship, machines, products, technology, money, etc.) of a state (nation-state).

(3) The natural environment: The natural environment as third subsystem is decisive for a sustainable development and provides people with a 'natural capital' (for example: resources, plants, variety of animals, etc.). 


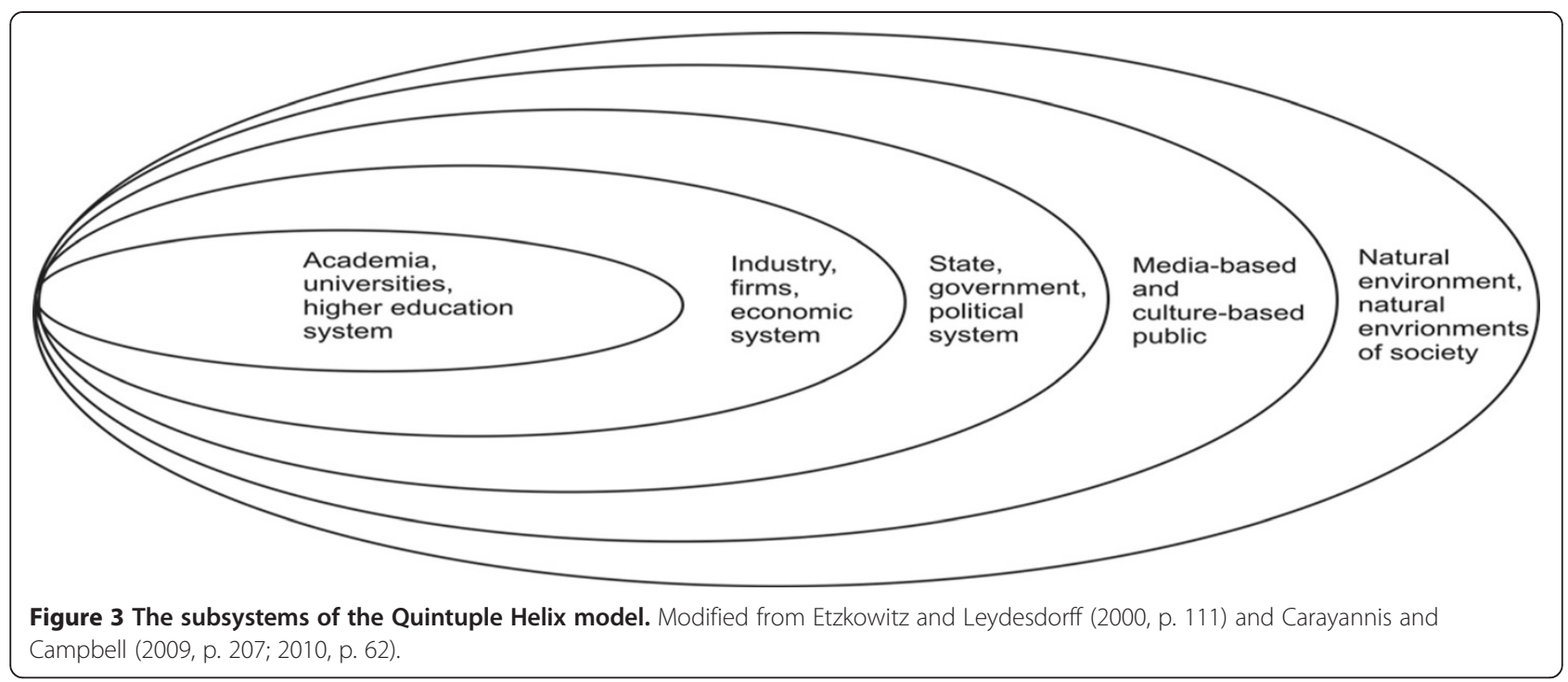

(4) The media-based and culture-based public: The fourth subsystem, media-based and culture-based public, integrates and combines two forms of 'capital'. On the one hand, this helix has, through the culture-based public (for example: tradition, values, etc.), a 'social capital'. On the other hand, the helix of media-based public (for example: television, internet, newspapers, etc.) contains also 'capital of information' (for example: news, communication, social networks).

(5) The political system: The political system, as a fifth subsystem, is also of crucial importance, because it formulates the 'will', where to the state (nation-state) is heading toward in the present and future, thereby also defining, organizing as well as administering the general conditions of the state (nation-state).

Therefore, this helix has a 'political and legal capital' (for example: ideas, laws, plans, politicians, etc.).

In summary, the Quintuple Helix Model can be described in the following way (see Figures 3 and 4): It is a theoretical and practical model for the exchange of the resource of knowledge, based on five social (societal) subsystems with 'capital' at its disposal, in order to generate and promote a sustainable development of society (Carayannis and Campbell, 2010, pp. 60-62). In this Cumulative Model of Quintuple Helix, the resource of knowledge moves through a circulation of knowledge from subsystemto-subsystem (see Barth 2011a, p. 6). This circulation of knowledge from subsystem-to-subsystem implies that knowledge has qualities of an input and output of and for subsystems within a state (nation-state) or also between states. If an input of knowledge is contributed into one of the five subsystems, then a knowledge creation takes place. This knowledge creation aligns with an exchange of basic knowledge and produces new inventions or knowledge as output. The output of knowledge creation of subsystems has therefore two routes (ways): (1) the first route leads to an output for the production of innovations for more sustainability in a state (nation-state); (2) the second route leads to an output on new know-how back into the circulation of knowledge. Through the circulation of knowledge, the new output of newly created know-how of a subsystem changes into input of knowledge for a different subsystem of the Quintuple Helix. (see Carayannis and Campbell 2010; Barth 2011a). About the input and output of knowledge, it can be said consequently:

"On the one hand, knowledge serves as an input or resource for advanced societies and economies, which increasingly depend on knowledge. On the other hand, knowledge production (knowledge creation) also generates knowledge as an output, which then is being fed back (recycled) as a knowledge input" (Carayannis and Campbell 2006, p. 4).

Therefore, in a Quintuple Helix by and with means of the five helices, the exchange of knowledge in a state (nation-state) is being dealt with all its conjunctions, in order to promote knowledge-production-based sustainable development.

\section{The challenge of global warming in a Quintuple Helix Model}

This brings us to the main question of our analysis: How can sustainable development, with regard to global warming, be practiced step-by-step within a Quintuple Helix Model? As we have seen, the resource of knowledge is the most important 'commodity' in a Quintuple Helix. The circulation of knowledge continually stimulates new 


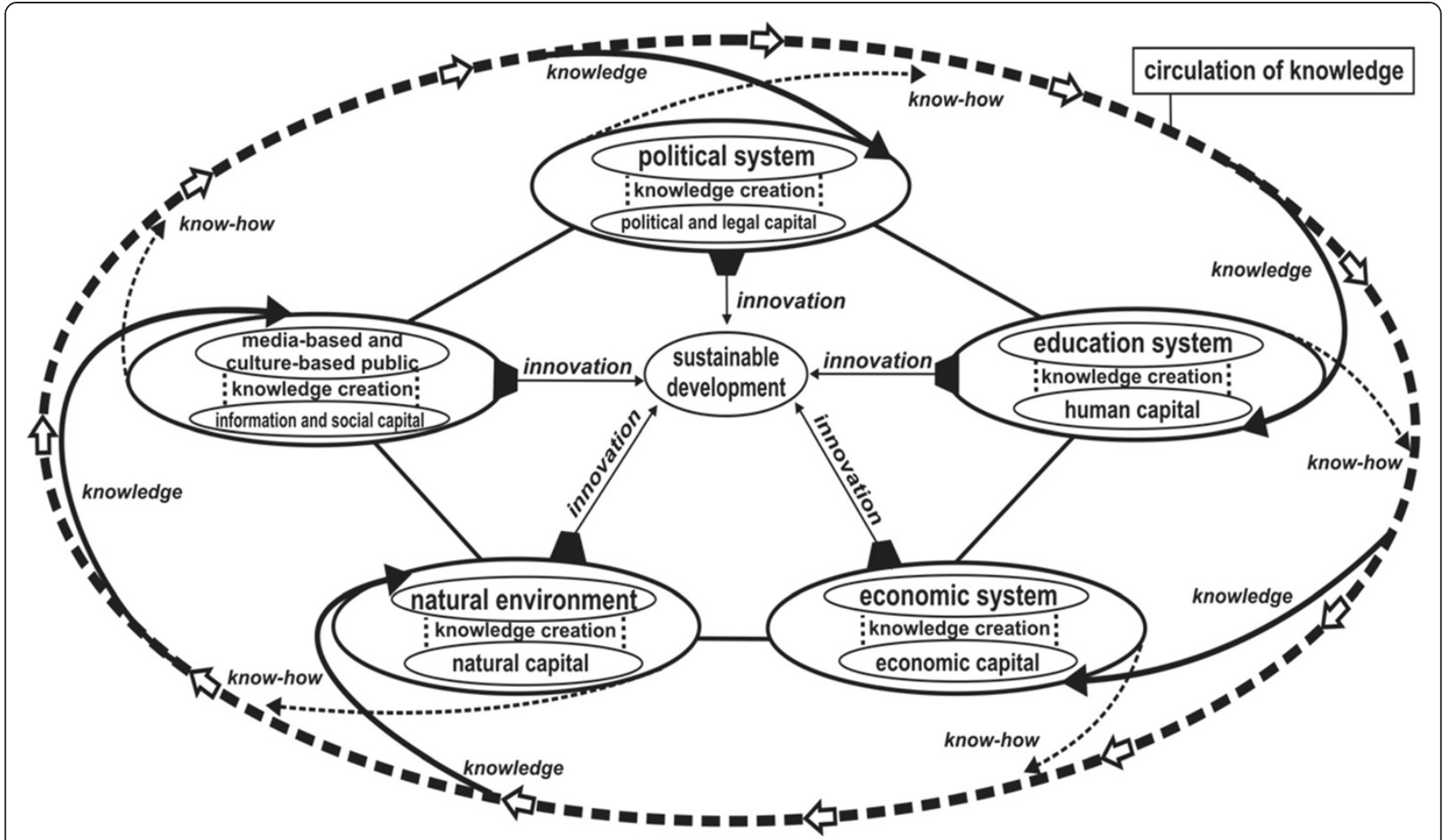

Figure 4 The Quintuple Helix model and its function (functions). Modified from Etzkowitz and Leydesdorff (2000), on Carayannis and Campbell $(2006,2009,2010)$, and on Barth (2011a).

knowledge. As a result, all systems in a Quintuple Helix influence each other with knowledge in order to promote sustainability through new, advanced and pioneering innovations. With the example of a targeted investment into the education system of the Quintuple Helix model, we will describe how more sustainable development can be considered feasible, in reference to 'global warming', for the national level and for positive effects that may arise for society (see Figure 5) in the following steps:

Step 1: When more investments flow into the helix of the education system to promote sustainable development under the aspect of global warming, the Quintuple Helix Model shows and demonstrates that, as an input, investments create new impulses and suggestions for knowledge creation in the education system. For example, targeted investments produce new equipment, new places for scientists and teachers, and a higher research opportunity. Therefore, a larger output of innovations from science and research can be obtained. At the same time, teaching and training can improve their effectiveness. Particularly, the investment in education should have a positive impact on human capital as a manifestation of output of the education system; because of more resources, teaching and training should be more effective, allowing the human capital to realize chances and to target uses more directly. The output that arises from human capital for a greener development or sustainable development is, in turn, also an input in the helix of the economic system.

Step 2: By means of input of new knowledge through human capital in the helix of the economic system, the value (values) of the knowledge economy or of an advanced knowledge economy consequently increases. Through the enhancement of knowledge, important further production facilities and development opportunities for a sustainable, future-oriented (future-sensitive) green economy, based on knowledge creation, can be stimulated and achieved. Not only that such a knowledge creation realizes in the economic system new types of jobs, new green products and new green services, also new and decisive impulses for green and greener economic growth are possible. In this subsystem, new values (like corporate social responsibility) are being demanded, enabling and supporting a new output of know-how and innovations by the economic system. Thus, in addition, Barth writes: 


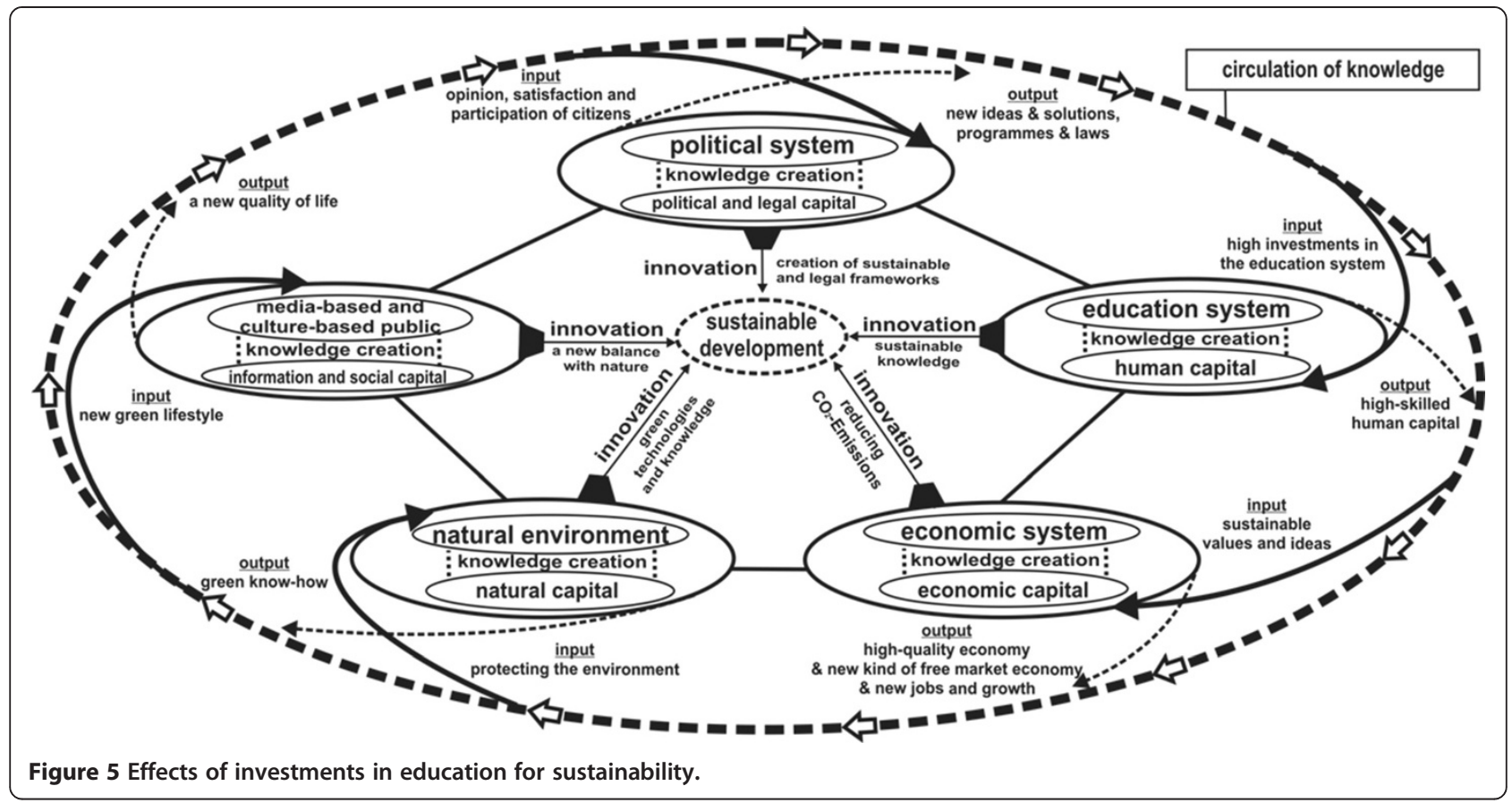

"The economic capital of know-how is in this context sustainability. Here, the output of economic know-how will be a high-quality and sustainable economy, but in fact, the special know-how which the economic system implies now, is probably a new harmony of human beings with nature" (Barth 2011a, p. 8).

Step 3: This new sustainability as an output of the economic system will be a new input of knowledge in the helix of natural environment. This new knowledge 'communicates' to nature that it will be increasingly protected, as lesser exploitation, destruction, contamination, and wastefulness (extravagance) is taking place. The natural environment can, thus, regenerate itself and strengthen its natural capital, and humanity can also learn again and further more from nature. (i.e., knowledge creation). The goal of this helix should be to live in balance with nature, to develop regenerative technologies and to use the available, finite resources sustainably and in a sensitive approach. Here, particularly natural science disciplines come into play, to form new green knowhow for humans. This know-how as output of the subsystem of the natural environment can provide more environmental protection and a superior quality of life to people. Moreover, the development of new environmental-friendly technologies can reduce the $\mathrm{CO}_{2}$ emissions more effectively and can aid in diminishing climate change. In summary, the following can be explained in context with Barth about the helix of natural environment: 'The output of the natural environment hence is a green knowhow' (Barth 2011a, p. 9).

Step 4: The output of the natural environment is followed by an input of new knowledge about nature and a green (greener) lifestyle for the subsystem of media-based and culture-based public. In this helix it is of a crucial importance to communicate and to live a green lifestyle. Here, the media-based public receives a new and crucial function (i.e., information capital), which is spreading through the media the information about a new green consciousness and the new human lifestyle. This capital should provide incentives on how a green lifestyle can be implemented in a simple, affordable, and conscious way (i.e., knowledge creation). This knowledge creation promotes the necessary social capital of the culture-based public, on which a society depends for sustainable development. This social capital, therefore, must pass on information about wishes, needs, problems, or satisfaction of citizens as output into politics or the political system. The know-how output of the media-based and culture-based public serves thereby as new input for the helix of the political system.

Step 5: The input of knowledge into the political system is the know-how from the media-based and culture-based public and represents also the 
collective knowledge from the three other subsystems of society. The important discussions on this new knowledge in the political systems are necessary impulses for knowledge creation. The goal of this knowledge creation is a 'political and legal capital', which makes the Quintuple Helix more effective, more high-quality, and more sustainable. Consequently, the newly obtained know-how is an output of suggestions, sustainable investments, and objectives. The new output of knowledge and knowhow of the political system leads across the circulation of knowledge back again into the education system, economic system, natural environment, and media-based and culture-based public.

\section{Conclusions}

In summary, as we illustrated by the example of the discussion in Section 'The challenge of global warming in a Quintuple Helix Mode' ('five-step flow analysis'), it should be clear that all systems in a Quintuple Helix perform a pivotal function, influencing each other. If more sustainable development is being considered (and demanded) on a national level, as a result of global warming, and if, for instance, more targeted investments in a specific helix of the Quintuple Helix start flowing, then there will be a positive impact on all other subsystems and on the society as a whole. The Quintuple Helix Model demonstrates that an investment in knowledge and a promotion of knowledge-production brings into play new and crucial impulses for innovation, know-how and the advancement of society. By initiating small steps toward sustainability, long-term and leading knowledge societies can emerge, which will live in balance with nature and ultimately, perhaps, lead to a green economic wonder.

To conclude, the Quintuple Helix Model makes it clear that the implementation of thought and action in sustainability will have a positive impact on the society as a whole. The new quality-management for more sustainability lies therefore in the creation of new knowledge, know-how, and innovation in balance with nature (see Carayannis and Campbell 2010, pp. 58-62). One chief objective of the Quintuple Helix is to enhance value in society through the resource of knowledge. The discussion about the Quintuple Helix Model indicates that striving for the promotion of knowledge as a knowledge nugget should be regarded as being essential (see Carayannis and Formica 2006, p. 152): This means that knowledge is the key to and for more sustainability and to a new quality of life. Today, knowledge is the most fundamental resource (Lundvall 1992, p. 1). Nevertheless, whether a state (nation-state or beyond-nation-state) is leading in different fields in the future, will be primarily, if not even solely, be decided by its potential to develop new knowledge, know how and innovation in balance with nature. However, the improved exchange of knowledge and the striving for knowledge, new know-how, and innovations through the Quintuple Helix Model can be, or at least, offer a solution for the challenges of sustainable development under the aspect of global warming in the twenty-first century.

Mastering and balancing ecological issues and challenges (such as global warming) are often being depicted and presented as a theme of survival for humanity in a global format. Consequently, the European Commission (2009) can assert the major need for a greater socioecological transition. Social ecology makes the context of the natural environments for society and economy more visible and emphasizes an understanding of interaction and codevelopment of society and environment (nature). The Quintuple Helix innovation model (Carayannis and Campbell 2010) bridges social ecology with knowledge production and innovation. Here, the natural environments of society and economy not only challenge, but also encourage and inspire knowledge production and innovation. In the approach of the Quintuple Helix innovation model, the naturalenvironments-of-society are being identified as opportunities for driving further and excelling the sustainable development and coevolution of knowledge economy, knowledge society, and knowledge democracy. This also has a potential of influencing the way how we perceive and organize entrepreneurship.

\section{Methods}

The article focuses on creatively designing and redesigning concepts on knowledge production and innovation. The points of departure are the Triple Helix, Quadruple Helix, and Quintuple Helix for innovation, and Mode 1, Mode 2, and Mode 3 for knowledge production. These concepts are all published and thus publicly accessible. The article engages in a detailed literature review on these concepts in their contextualization. The concept of the Quintuple Helix innovation system is being analytically applied to the ecological (socio-ecological) issue of global warming.

\section{Endnotes}

${ }^{\text {a }}$ The definition of the Brundtland Commission states that sustainable development 'meets the needs of the present without compromising the ability of future generations to meet their own needs' (United Nations 1987a, b).

${ }^{\mathrm{b}}$ The area of financial and economic system refers to financial and economic aspects of the effects of climate 
change. The following question arises (among other things): How should the two systems effectively change or adapt with-each-other in order to reduce or exclude crises in consequence of climate change (see for example: Barbier 2009; Barth 2011a; Green New Deal Group 2008; Hufbauer et al. 2009; Meyer 2008; OECD 2010; Sen 2007)?

${ }^{\mathrm{c}}$ The area of environmental challenges has to do with causes and effects of climate change and which political and social measures should be taken to increase environmental conservation and sustainability (see, for example: IPPC 2007a,b; Giddens 2009; Høyer 2010a; Müller and Niebert 2009; Stern 2009).

${ }^{\mathrm{d}}$ The area of feed and heal the world challenges emphasizes new and solution-oriented approaches under the aspect of knowledge and care in the course of climate change (see Parker 2010; Höll 2006).

${ }^{\mathrm{e}}$ The area of energy challenges highlights new green technologies and renewable energy, which lead to sustainable development (see also Barbier 2009; Green New Deal Group 2008; Høyer 2010b; UNEP 2008).

${ }^{f}$ The area of educational challenges is based on a better education as a key for empowerment, equality of chances and new knowledge for sustainability and development (see, for example, OECD 2009; O'Donnell 2004; Sen 2007; UNDP 2010).

${ }^{\mathrm{g}}$ The area of political democratic reform across the world promotes democracy as being a local and global key for sustainable development. Here, also the themes of democratization, freedom, equality, policy-making, gender, and political culture are relevant (see, furthermore, Barth 2011b; Biegelbauer 2007b; Campbell 2007; Campbell and Schaller 2002; Kreisky and Löffler 2010; Otzelberger 2011; Ulram 2006).

${ }^{\mathrm{h}}$ The area of transformative government across the world has to do with the political standing or rating of a nation-state. Examples here are the search for democracy, quality of democracy, types of political systems, etc. (see also Barth 2010, 2011a, b, c; Campbell 2008; Campbell and Barth 2009; Campbell et al. 2010; Diamond and Morlino 2005; O'Donnell 2004; Rommetveit et al. 2010; Schumpeter 1976; Tilly 2007).

${ }^{\mathrm{i}}$ The area of equity and security across the world refers to equity and security as being basic prerequisites to foster and support sustainable development (see, for example, UNDP 2011; Barth 2011a).

${ }^{j}$ The area of technology, innovation and entrepreneurship as drivers of knowledge societies emphasizes the fact that a sustainable development in knowledge societies can only be achieved when new knowledge is promoted and produced and when innovations (with a new entrepreneurship) are developed further (see here the idea and concept of the 'Academic Firm', Campbell and Güttel 2005; see also and furthermore Bhaskar 2010;
Biegelbauer 2007a; Campbell 2006; Carayannis and Campbell 2006, 2009, 2010, 2011; Dubina 2009; Dubina et al. 2012; Kuhlmann 2001; Lundvall 1992; Nowotny et al. 2003).

\section{Competing interests}

The authors declare that they have no competing interests.

\section{Author details}

'Department of Information Systems and Technology Management, George Washington University, School of Business, Washington, DC 20052, USA. ${ }^{2}$ Democracy Ranking Organization, Vienna, Austria. ${ }^{3}$ University of Klagenfurt, Faculty for Interdisciplinary Studies (IFF), Institute of Science Communication and Higher Education Research (WIHO), Schottenfeldgasse 29, Vienna A-1070, Austria. ${ }^{4}$ Department of Political Science, University of Vienna,

Universitätsstrasse 7/2, Vienna A-1010, Austria.

\section{Authors' contributions}

EGC designed, innovated and provided the overall conceptual framework for analysis. TDB concentrated in detail on the literature review and its ramifications. DFJC focused on framing the concept of the Quintuple Helix innovation system in context of application to global warming. All authors engaged and cross-engaged in writing. All authors read and approved the final manuscript.

\section{Authors information}

http://www.democracyranking.org/en/.

Received: 8 June 2012 Accepted: 8 August 2012

Published: 8 August 2012

\section{References}

Barbier, EB (2009). Rethinking the economic recovery: a global green new deal. United Nations Environment Program (UNEP). http://www.unep.org/ greeneconomy/portals/30/docs/GGND-Report-April2009.pdf. Accessed 31 March 2012.

Barth, TD (2010). Konzeption, Messung und Rating der Demokratiequalität. Brasilien, Südafrika, Australien und die Russische Föderation 1997-2006 (2010th ed.). Saarbrücken: VDM-Verlag Dr. Müller.

Barth, TD (2011a). The idea of a green new deal in a Quintuple Helix Model of knowledge, know-how and innovation. International Journal of Social Ecology and Sustainable Development, 1(2), 1-14.

Barth, TD (2011b). Freiheit, Gleichheit, Demokratiequalität: Zur Qualitätsmessung in den Top 20 Demokratien des Democracy Rankings [Freedom, Equality and the Quality of Democracy: Measuring Quality in the Top 20 Democracies of the Democracy Ranking] Dissertation (Doctoral Thesis). Vienna: University of Vienna.

Barth, TD (2011c). Die 20 besten Demokratien der Welt. Freiheit - Gleichheit Demokratiequalität auf einen Blick. 1. Norderstedt/Wien: Auflage, Books on Demand Verlag.

Bhaskar, R (2010). Context of interdisciplinarity: interdisciplinarity and climate change. In R Bhasakar, C Frank, KG Høyer, P Næss, \& J Parker (Eds.), Interdisciplinarity and climate change: Transforming knowledge and practice for our global future (pp. 1-24). New York: Routledge.

Biegelbauer, P (2007a). Learning from abroad: the Austrian competence centre programme Kplus. Science and Policy, 34(9), 606-618.

Biegelbauer, P (2007b). Ein neuer Blick auf politisches Handeln: Politik-Lernansätze im Vergleich. Österreichische Zeitschrift für Politikwissenschaft (ÖZP), 36(3), 231-247.

Campbell, DFJ, \& Schaller, C (Eds.). (2002). Demokratiequalität in Österreich Zustand und Entwicklungsperspektiven. Opladen: Leske + Budrich.

Campbell, DFJ, \& Güttel, WH (2005). Knowledge production of firms: research networks and the-scientification of business R\&D. International Journal of Technology Management, 31(1/2), 152-175.

Campbell, DFJ (2006). In EG Carayannis \& DFJ Campbell (Eds.), Knowledge creation, diffusion, and use in innovation networks and knowledge clusters. A comparative systems approach across the United States, Europe and Asia (pp. 67-100). Westport: Praeger. 
Campbell, DFJ (2007). Wie links oder wie rechts sind Österreichs Länder? Eine komparative Langzeitanalyse des parlamentarischen Mehrebenensystems Österreichs (1945-2007). SWS-Rundschau, 47(4), 381-404

Campbell, DFJ (2008). The basic concept for the democracy ranking of the quality of democracy. Vienna: Democracy Ranking. http://www.democracyranking. org/downloads/basic_concept_democracy_ranking_2008_A4.pdf. Accessed 31 March 2012

Campbell, DFJ, \& Barth, TD (2009). Wie können Demokratie und Demokratiequalität gemessen werden? Modelle, Demokratie-Indices und Länderbeispiele im globalen Vergleich. SWS-Rundschau, 49(2), 208-233.

Campbell, DFJ, Pölzlbauer, P, \& Barth, T D (2010). Das "Democracy Ranking 2010 of the Quality of Democracy" - Erstveröffentlichung (German). Vienna: Democracy Ranking. http://www.democracyranking.org/downloads/ Democracy_Ranking_Concept_Earlyrelease_German_2010.pdf. Accessed 31 March 2012.

Carayannis, EG (2004). Measuring intangibles: managing intangibles for tangible outcomes in research and innovation. International Journal of Nuclear Knowledge Management, 1(2), 49-67.

Carayannis, EG, \& von Zedtwitz, M (2005). Architecting gloCal (global - local), real-virtual incubator networks (G-RVINs) as catalysts and accelerators of entrepreneurship in transitioning and developing economies. Technovation, $25,95-110$.

Carayannis, EG, \& Campbell, DFJ (2006). In EG Carayannis \& DFJ Campbell (Eds.), Knowledge creation, diffusion, and use in innovation networks and knowledge clusters. A comparative systems approach across the United States, Europe and Asia (pp. 1-25). Westporti: Praeger.

Carayannis, EG, \& Alexander, JM (2006). Global and local knowledge. Palgrave MacMillan: Glocal transatlantic public-private partnerships for research and technological development. Houndmills.

Carayannis, EG, \& Formica, P (2006). Intellectual venture capitalists: an emerging breed of knowledge entrepreneurs - viewpoint. Industry and Higher Education, 20(3), 151-156

Carayannis, EG, \& Campbell, DFJ (2009). "Mode 3" and "Quadruple Helix": toward a 21st century fractal innovation ecosystem. International Journal of Technology Management, 46(3/4), 201-234.

Carayannis, EG, \& Kaloudis, A (2010). 21st century democratic capitalism: a time for action and a time to lead. International Journal of Social Ecology and Sustainable Development, 1(1), 1-13.

Carayannis, EG, \& Campbell, DFJ (2010). Triple Helix, Quadruple Helix and Quintuple Helix and how do knowledge, innovation and the environment relate to each other? A proposed framework for a trans-disciplinary analysis of sustainable development and social ecology. International Journal of Social Ecology and Sustainable Development, 1(1), 41-69. http://www.igi-global.com/ bookstore/article.aspx?titleid=41959.

Carayannis, EG (Ed.). (2011). Planet earth 2011 - global warming challenges and opportunities for policy and practice. Open Access Publisher. http://www. intechopen.com/books/planet-earth-2011-global-warming-challenges-andopportunities-for-policy-and-practice. Accessed 31 March 2012.

Carayannis, EG, \& Campbell, DFJ (2011). Open innovation diplomacy and a 21st century fractal research, education and innovation (FREIE) ecosystem: building on the Quadruple and Quintuple Helix innovation concepts and the "Mode 3" knowledge production system. Journal of the Knowledge Economy, 2(3), 327-372. http://www.springerlink.com/content/d1lr223321305579/.

Carayannis, EG, \& Campbell, DFJ (2012). Mode 3 knowledge production in quadruple helix innovation systems. 21st-century democracy, innovation, and entrepreneurship for development. SpringerBriefs in business (Vol. 7). New York: Springer. http://www.springer.com/business+\%26+management/book/978-14614-2061-3

Danilda, I, Lindberg, M, \& Torstensson, B-M (2009). Women Resource Centres. A Quattro Helix Innovation System on the European Agenda. Paper. http:// www.hss09.se/own_documents/Papers/3-11\%20-\%20Danilda\%20Lindberg\% 20\&\%20Torstensson\%20-\%20paper.pdf. Accessed 31 March 2012.

Diamond, L, \& Morlino, L (2005). Introduction. In L Diamond \& L Morlino (Eds.), Assessing the quality of democracy ( $p p$. ix-xliii). Baltimore: The John Hopkins University Press.

Dubina, I N (2009). Управление творчеством персонала в условиях инновачионной экономики [Creativity Management in the Innovation Economy]. Moscow: Academia.

Dubina, I N, Carayannis, EG, \& Campbell, D FJ (2012). Creativity economy and a crisis of the economy? Coevolution of knowledge, innovation, and creativity, and of the knowledge economy and knowledge society. Journal of the
Knowledge Economy, 3(1), 1-24. http://www.springerlink.com/content/ t5j8112136h526h5/.

Etzkowitz, H, \& Leydesdorff, L (2000). The dynamics of innovation: from National Systems and "Mode 2" to a Triple Helix of university-industry-government relations. Research Policy, 29, 109-123.

European Commission. (2009). The World in 2025. Rising Asia and socio-ecological transition. Brussels: European Commission. http://ec.europa.eu/research/socialsciences/pdf/the-world-in-2025-report_en.pdf. Accessed 31 March 2012.

Fischer-Kowalski, M (1998). Society's metabolism. The intellectual history of materials flow analysis, Part I, 1860-1970. Journal of Industrial Ecology, 2(1), $61-78$.

Fischer-Kowalski, M, \& Hüttler, W (1999). Society's metabolism. The intellectual history of materials flow analysis, Part II, 1970-1998. Journal of Industrial Ecology, 2(4), 107-136.

Fischer-Kowalski, M, \& Haberl, H (Eds.). (2007). Socioecological transitions and global change. Trajectories of social metabolism and land use. Cheltenham: Edward Elgar.

Friedman, TL (2008). Hot, flat and crowded: why we need a green revolution - and how we can renew our global future. London: Penguin.

Gibbons, M, Limoges, C, Nowotny, H, Schwartzman, S, Scott, P, \& Trow, M (1994). The new production of knowledge. The dynamics of science and research in contemporary societies. London: Sage.

Giddens, A (2009). The politics of climate change. Cambridge/Malden: Polity Press. Green New Deal Group. (2008). A green new deal: joined-up policies to solve the triple crunch of the credit crisis, climate change and high oil price - the first report of the Green New Deal Group. London: New Economic Foundation. http://www.neweconomics.org/sites/neweconomics.org/files/ A_Green_New_Deal_1.pdf. Accessed 31 March 2012.

Haberl, H, Fischer-Kowalski, M, Krausmann, F, Weisz, H, \& Winiwarter, V (2004). Progress towards sustainability? What the conceptual framework of material and energy flow accounting (MEFA) can offer. Land Use Policy, 21(3), 199-213.

Hopwood, B, Mellor, M, \& O'Brien, G (2005). Sustainable development: mapping different approaches. Sustainable Development, 13, 38-52.

Høyer, KG (2010a). Seven theses on $\mathrm{CO}^{2}$ reductionism and its interdisciplinary counteraction. In R Bhasakar, C Frank, KG Høyer, P Næss, \& J Parker (Eds.), Interdisciplinarity and climate change: transforming knowledge and practice for our global future (pp. 35-53). New York: Routledge.

Høyer, KG (2010b). Technological idealism: the case of the thorium fuel cycle. In R Bhasakar, C Frank, KG Høyer, P Næss, \& J Parker (Eds.), Interdisciplinarity and climate change: transforming knowledge and practice for our global future (pp. 164-182). New York: Routledge.

Höll, O (2006). Entwicklungspolitik. In H Dachs (Ed.), Politik in Österreich. Das Handbuch (pp. 884-904). Wien: MANZ'sche Verlags- und Universitätsbuchhandlung.

Hufbauer, GC, Charnovitz, S, \& Kim, J (2009). Global warming and the world trading system. Washington, DC: Person Institute for International Economics.

IPPC. (2007a). Historical overview of climate change science. In S Solomon, D Qin, M Manning, Z Chen, M Marquis, KB Averyt, M Tignor, \& HL Miller (Eds.), Climate Change 2007: The physical science basis - the fourth assessment report of the intergovernmental panel on climate change (pp. 93-127). Cambridge, United Kingdom and New York, USA: Cambridge University Press.

IPPC. (2007b). Climate change 2007: The physical science basis - errata for the working Group - fourth assessment report. Cambridge, United Kingdom and New York, USA: Cambridge University Press. http://www.ipcc.ch/pdf/ assessment-report/ar4/wg1/ar4-wg1-errata.pdf. Accessed 31 March 2012.

Kates, RW, Clark, WC, Corell, R, Hall, J M, Jaeger, CC, Lowe, I, McCarthy, JJ, Schellnhuber, HJ, Bolin, B, Dickson, NM, Faucheux, S, Gallopin, GC, Grübler, A, Huntley, B, Jäger, J, Jodha, NS, Kasperson, RE, Mabogunje, A, Matson, P, Mooney, H, Moore, B, III, O'Riordan, T, \& Svedin, U (2001). Environment and development: sustainability science. Science, 292(5517), 641-642.

Krausmann, F, Fischer-Kowalski, M, Schandl, H, \& Eisenmenger, N (2008). The global sociometabolic transition: past and present metabolic profiles and their future trajectories. Journal of Industrial Ecology, 12(5), 637-656.

Kreisky, E, \& Löffler, M (2010). Demokratietheorieentwicklung im Kontext gesellschaftlicher Paradigmen. Österreichische Zeitschrift für Politikwissenschaft, 39(4), 89-104

Kuhlmann, S (2001). Future governance of innovation policy in Europe - three scenarios. Research Policy, 30, 953-976.

Le Monde diplomatique (Ed.). (2009). Atlas der globalisierung - sehen und verstehen, was die welt bewegt. Paris/Berlin: Le Monde diplomatique/taz. 
Lundvall, B-Å (Ed.). (1992). National systems of innovation. Towards a theory of innovation and interactive learning. London: Pinter Publishers.

Meyer, B (2008). Wie muss die wirtschaft umgebaut werden? Perspektiven nachhaltiger Entwicklung, Lizenzausgabe für die bundeszentrale für politische bildung. Frankfurt am Main/Bonn: Fischer Taschenbuch Verlag.

Müller, M, \& Niebert, K (2009). Epochenwechsel - plädoyer für einen grünen new deal. München: Oekom Verlag.

Nowotny, H, Scott, P, \& Gibbons, M (2003). Mode 2 revisited: the new production of knowledge. Minerva, 41, 179-194.

O'Donnell, G (2004). Human development, human rights, and democracy. In G O'Donnell, JV Cullell, \& OM lazzetta (Eds.), The quality of democracy. Theory and applications (pp. 9-92). Notre Dame, Indiana: University of Notre Dame Press.

OECD. (2009). OECD-Factbook 2009 - economic, environmental and social statistics - special focus: inequality. Paris: OECD Publishing.

OECD. (2010). OECD-Factbook 2010 - economic, environmental and social statistics - special focus: the crisis and beyond. Paris: OECD Publishing.

Otzelberger, A (2011). Gender-responsive strategies on climate change: Recent progress and ways forward for donors. BRIDGE: development - gender. Brighton: Institute of Development Studies. http://www.bridge.ids.ac.uk/vfile/ upload/4/document/1107/Gender\%20responsive\%20strategies\%20on\% 20climate\%20change_progress\%20and\%20ways\%20forward\%20for\% 20donors.pdf.

Parker, J (2010). Towards a dialectics of knowledge and care in the global system. In R Bhasakar, C.Frank, K G Høyer, P Næsss, \& J Parker (Eds.), Interdisciplinarity and climate change: transforming knowledge and practice for our global future (pp. 205-226). New York: Routledge.

Rommetveit, K, Funtowicz, S, \& Strand, R (2010). Knowledge, democracy and action in response to climate change. In R Bhasakar, C Frank, K G Høyer, P Næss, \& J Parker (Eds.), Interdisciplinarity and climate change: transforming knowledge and practice for our global future (pp. 149-163). New York: Routledge.

Schumpeter, J A (1976). Capitalism, socialism and democracy. New York: Harper Perennial.

Sen, A (2007). Ökonomie für den Menschen - Wege zur Gerechtigkeit und Solidarität in der Marktwirtschaft; Aus dem Englischen von C. Goldmann (4th ed.). München: Deutscher Taschenbuch Verlag.

Stern, N (2009). The global deal - climate change and the creation of a new era of progress and prosperity. New York: Public Affairs.

Tilly, C (2007). Democracy. New York: Cambridge University Press.

Ulram, PA (2006). Politische Kultur der Bevölkerung. In H Dachs (Ed.), Politik in Österreich. Das Handbuch (pp. 513-524). Vienna: MANZ'sche Verlags- und Universitätsbuchhandlung.

United Nations. (1987a). Report of the world commission on Environment and Development (42/187). New York: United Nations. http://www.un-documents. net/a42r187.htm. Accessed 31 March 2012.

United Nations. (1987b). Report of the World Commission on Environment and Development: "our common future". New York: United Nations. http:// worldinbalance.net/pdf/1987-brundtland.pdf. Accessed 31 March 2012.

UNDP. (2007). Human Development Report 2007/2008. Fighting climate change: human solidarity in a divided world. New York: United Nations Development Program. http://hdr.undp.org/en/reports/global/hdr2007-2008. Accessed 31 March 2012.

UNDP. (2010). Human Development Report 2010 (20th Anniversary Edition) - The real wealth of nations: pathways to human development. New York: United Nations Development Program. http://hdr.undp.org/en/media/ HDR_2010_EN_Complete_reprint.pdf. Accessed 31 March 2012

UNDP. (2011). Human Development Report 2011 - Sustainability and equity: a better future for all. New York: United Nations Development Program. http:// hdr.undp.org/en/reports/global/hdr2011/. Accessed 31 March 2012.

UNEP. (2008). Green jobs: towards decent work in sustainable, low-carbon world. Washington/New York: United Nations Environment Program. http://www. unep.org/labour_environment/PDFs/Greenjobs/UNEP-Green-Jobs-Report.pdf. Accessed 31 March 2012

doi:10.1186/2192-5372-1-2

Cite this article as: Carayannis et al:: The Quintuple Helix innovation model: global warming as a challenge and driver for innovation. Journal of Innovation and Entrepreneurship 2012 1:2.

\section{Submit your manuscript to a SpringerOpen ${ }^{\odot}$ journal and benefit from:}

- Convenient online submission

- Rigorous peer review

- Immediate publication on acceptance

- Open access: articles freely available online

- High visibility within the field

- Retaining the copyright to your article

Submit your next manuscript at $\gg$ springeropen.com 